\title{
Nation and Political Economy-A Reflection on List
}

\author{
Milena Fernandes de Oliveira \\ University of Campinas-São Paulo-Brazil
}

\begin{abstract}
The article intends to work about Friedrich List political economy starting from a specific point of view: idea of nation. Published in 1841, The National System of Political economy establishes a hard dialogue with the Wealth of nations written by Smith. The criticism is built around the idea of nation. In List, the nation, as synonym of productive forces, is a critic to the Smith's nation idea as a free market. The List's idea of nation is a product of a group of structural (and not only cultural or mental) transformations that occurred during the Revolutions of 1830 and 1848 in Europe. The result is the emergency of a new form of State, the nation-State. The political economy elaborates their critics in the measure in capitalism changes. The nation, in the national system of political economy of List, synthesizes the unification of the territory, the consolidation of the national industry and an internal market free from barriers and interlinked by a modern net of transports. In a contradictory way, that nation idea is based in great territory and its empire and not on the nationality principle, according to which, each people, yet that very small, has the right to its own territory. The unified and industrially developed States build immense empires that, in practical terms, contravene the principle of nationality.
\end{abstract}

Keywords: Nation, political economy, Smith, List, capitalism

\section{Introduction}

This paper relates the emergence of a "new" political economy in the first half of nineteenth century and the idea of nation, arising from the movement of people's Spring of 1848. This political economy, expressed here by List's idea, is opposed to the political economy of the third quarter of the eighteenth century, especially the English political economy, represented in Adam Smith's thought. The supposition of this paper is that the List's political economy is related to the formation of German nation and its unification process.

When we say a "new" political economy it means a new way of conceiving the society based on material progress, which has as implication the proposal of a new relation between economy and the national State and between this and civil society. This new relation was evoked by the industrialization of England and the spirit of the nineteenth century that understood material progress as capitalist industrialization. The continental European countries perceived that their place in the world depended on their industrial forces, and these were the necessary way to an extensive world empire.

In this paper, we conceive political economy as a comprehension of the development of capitalist society, which organizes its operating mechanisms and also provides a critique of the present moment:

Milena Fernandes de Oliveira, professor, University of Campinas-São Paulo-Brazil. 
Every global view of history is a genealogy of the present. It selects and sorts facts from the past that conduce in sequence to deal with the present configuration, almost always with the intention, consciously or not, to justify it. Therefore, the historian shows an orderly succession of triggering events until it is considered "natural" the social reality in which he lives and works (...) it is not an individual reworking of past evidences in light of historian's concerns, but in something collective with a social function. (...) The description of the present (...) completed with what I call, generically, a "political economy", that is, an explanation of the system of relations between men, which serves to justify them and to rationalize them. (...) From this evolution from past to present, mediated by the political economy filter, we obtain a projection to the future: a social project that is expressed in a policy proposal. (FONTANA, 1982, own trans, p. 10)

In the mid-nineteenth century, british capitalism had already defined his mainly elements - textile and coal industry, land ownership system, free labor, a liberal State - and began to spread to the European continent. Then, a new moment in capitalist industrialization began, and to promote it, the rise of nation-states was crucial. The iron and chemical industry, the production of capital goods, the construction of railway roads, the arms industry, they all required a great amount of initial investiment and the national State was the most important investor (HOBSBAWM, 1999).

Germany was the center of the construction of this "new" political economy due to its own historical contradictions: differences between east and west feudal system before accelerated modernization process; uncentralized State due to the tension between local and universal power of the Holy Roman Empire; alliance between powerful landlords and industrial owners; intellectual leadership driven by a middle class, formed during the unification process and by the new demands that emerged from this process (Sozialpolitiker); romanticism ideology against rationalism. From these contradictions the German Historical School was born, whose ideas will help to compose a new way of conceiving the relation between economics and politics.

The understanding of German political economy of the first half of the nineteenth century involves, necessarily, the idea of nation, whose ultimate expression is Friedrich List's work, National System of Political Economy. After the Napoleonic Wars, the territory which today corresponds to Germany became a set of 360 small territories, clearly divided between a modern West (the Confederation of the Rhine), influenced by the French occupation, and a backward East, where Prussia was situated. The resistance against the French occupation encouraged the birth of a German nationalist movement. It's the beginning of German nationalism, a nationalism that derives from the ruins of the Holy Roman Empire and Ancien Régime, beated by Napoleon's Army: "A more intense and better-defined German nationalism, a real national movement, grew out of the experience of Napoleonic Wars. This national movement as carried by the 'Bildungsbürgertum', i.e., the educated urban elite. (...) poets and thinkers, scholars, composers, and artists joined in a kind of "Kulturpatriotismus". Together, they created a "Kulturnation" (Pohlsander, 2008, p. 28). Although this first movement, the German Confederation was created by the German princes, gathering a lot of micro-states with their own constitutions, restoring the monarchic order. The nationalist movements went on, inspired specially by the July Revolutions in 1830 in France and Poland, and were repressed by authoritarian powers with a great dose of violence.

List, who began teaching at the University of Tübingen in 1817, tries to connect the low standard of living in Germany to the non-unification through which had undergone the other European States. For the thinkers of the later eighteenth century and the beginning of nineteenth, national unification was the basis of liberty. It is by the problem of unification that List became closer to the classical political economy (he also taught political 
economy at the University of Tübingen during the period he stayed there), criticizing it on the argument that “(...) the popular theory took no account of nations, but simply of the entire human race on the one hand, or of single individuals on the other" (LIST, 1909 (1841), p. xl). For Germany to become a nation able to compete with England, it was imperative the unification, aiming at the development of the national productive forces and "the abolition of our internal tariffs and the adoption of a common commercial policy for the whole of Germany" (LIST, 1909 (1841), p. xli).

It must be clear that nationalism has a complex and specific relation with the unification process and the formation of modern State in Germany. As Italy, there were not evident frontiers from what nationalism could be constructed. After all, it is possible to establish multiple relations between State, nation and territory, which expresses a lot of temporalities. The national system of political economy, thought by List, is inspired in this historical fact. The forthcoming of a political economy before the nationalism itself may be a clue to the possible relation between capitalism and the idea of nation.

Nationalism was more important as a product than a cause of national unification. There was a limited nationalist movement in both countries [Germany and Italy]. Their major contributions to unification were to provide legitimating for unity in the eyes of outsiders and essential elite co-ordination for the effective running of the new state once the initial act of unification had been carried through. The crucial interventions of Prussia and Piedmont were not inspired by nationalism. Nationalism had little popular appeal. What nationalism there was of political significance was rather different from the romantic, linguistic and ethnic ideas which intellectual historians have emphasized. (BREUILLY, 1994, p. 96)

Before we describe the relations between the political economy and the List's idea of nation, some preliminary considerations about what is called economic nationalism are necessary.

Political economy is here understood as the science of nascent capitalism. It is not restricted, however, to think on a society that is born from industrialization and illustration process. Political economy is also responsible for a future projection, which overcomes inequalities and injustices of the present society. In this sense, political economy, as the capitalism science, is linked to the utopia of a society with free and equal individuals. It is the understanding of the present, while the liberal utopia is a future project (FONTANA, 1982).

Therefore, from the capitalist development emerges the political economies, as comprehension or criticism of the system. The most recent political economy puts down the previous one, imagining that capitalism reproduces itself with inequality and injustice. Ricardo and Smith were criticized by List as having thought that the political economy was universal and the nations could be treated as simple fractions of the world. Marx also condemned Ricardo and Smith for not seeing the historical foundations of the present and, then, of the political economy. To Marx, the classical political economy treated the categories as natural categories, not as if they were historically constructed. As said by Fontana, the political economy should be understood not only as a science, but also as a comprehension of the present time:

The description of the present time — product of historical evolution — gets complete with what I call, generically, a "political economy", that is, an explanation of the system of relations that exist between men, which serves to justify and rationalize them — and with the relations, the elements of inequality and exploitation that include — presenting them as a form of social division of labor and functions, which not only appears now as a result of historical progress, but as a form of organization that maximizes the common good. Each stage of social evolution, each systematization of inequality and exploitation, had its own political economy, its on rationalization of the established order, and set it in a proper historical view. (FONTANA, trans, 1998, pp. 9-10) 
Therefore, we can speak of "political economies" and "criticism of political economies". Our intention, in this paper, is to focus on one of these criticisms, which Friedrich List directs to the English school of political economy, from a point of view: the idea of nation.

Given the late unification, Germany gives us a privileged field of the nation idea, and the novelty that this idea reveals in the nineteenth century, in its close relation to political economy. The relation between economy and politics that in mercantilism was centered in the relation between economy and monarchic States, is now seen as the relation between economy and nation:

The term originated in the seventeenth and eighteenth centuries to refer to the economic policies of the nation-states of the time. The writings of that period (such as by the Physiocrats and Mercantalists) focused on taxes and trade policy. The meaning of the term was broadened in the nineteenth century to refer to the manifold ways in which capitalist economic structures and market processes influenced, and were influenced by, political power at local, national and international levels. (Adler, 2010, p. 181)

It is also Germany, the center of the philosophical thought, which will be the heart of a new way of thinking about the nation. This nation in nineteenth is designed by the existence of a spirit, but also by its concrete forms, its frontiers (real and imagined ones) and its productive forces which are, according to List, the essence of the nationality. The study of the development of these productive forces is what should be the object of political economy. By the study of the List's political economy we can take in the relation between the idea of nation and capitalism more clearly, precisely because it captures the fact that to German develop its capitalism it's necessary to develop itself as a nation. The absence of the unification among German states is responsible for its economic backwardness. Protectionism is the most important ally in this process that conforms the nation and the capitalist productive forces at once.

The formation of new nations in the nineteenth century - either by unification of small territories or by fragmentation of ancient empires-demonstrates the strength of the economic settling of the nation. It is a complete new conception of nation that articulates the new territories: the nation as an economic unit. Our question, in this article, comes from the following question: Why does the nation in the nineteenth century begin to be defined by its economic elements? Following the ideas of Ernest Gellner, we could say that if nationalism rises as an ideology of industrial society, political economy is the understanding of its foundations and then a relation between the idea of nation and the political economy is traced, as both are artifacts of the modern era:

(...) there are the direct consequences of industrialization itself. The general and pervasive consequences of an established industrial order have already been discussed, in connection ith our general model linking the industrial division of labour with the implementation of the nationalist principle. But certain specific consequences of early industrialization which do not generally persist later nevertheless have a significant role to play. Early industrialism means population explosion, rapid urbanization, labour migration, and also the economic and political penetration of previously more or less inward-turned communities, by a global economy and a centralizing polity. (Gellner, 2008, p. 41)

For us, Germany has a crucial position in this new definition of nation and is the epicenter of the national revolutions that characterize the Spring of Peoples. After the devastation that followed the Napoleonic wars and given the German backwardness in relation to England, policymakers raised the question of territorial unification and formation of German unity. The unification was a practical question, but this question as reinforced by the reflection on a possible German nationality or common German spirit, as it was considered by the romantic 
movement. According to Anderson, the nation is an imagined community, but for us, not only this. In capitalism, nation is redefined, inexorably, by concrete ties, by national industry, by productive forces that compose, as List says, the prime foundation of nationality. In the process of German constitution as a nation, and precisely because the nation and capitalism are conformed at the same time, these concrete aspects appear with an unprecedented clarity.

Late unifications and its relationship to national constructions is a topic of extreme complexity. They are covered by the veil of the incomplete dissolution of the feudal world and its unfinished passage to the modern world. Traces of modern State and modern market live with territorial fragmentation and another heritages from the medieval world, as the multiples customs tariffs, private use of violence and disputes inside noble class. Both Germany and Italy, which characterize examples of late unification (Poland is also considered a late unification), still had remnants of medieval powers, respectively, the Holy Roman Empire and the Papacy. As told by Perry Anderson, this universal powers (the Empire and Papacy) avoided the territorial unification, centered in the figure of the king: "It's clear, of course, that the universalist mediaeval institutions of the Papacy and the Empire acted to check the development of an orthodox territorial monarchy in both Italy and Germany" (Anderson, p. 143). The result was a series of micro-powers that maintained the control of the violence and had theirs own taxes and tributes.

Therefore, the unification corresponds also to the formation of a national market, from which the society of trade and production to exchange unfold. The unification means, in an economic sense, the abolition of multiple tariffs and taxes. As Weber remarks, politics and economics are together during the formation of capitalism; the market is the economic counterpart of the modern State:

The economic functions of Absolutism were not exhausted, however, by its tax and office systems. Mercantilism was the ruling doctrine of the epoch, and it presents the same ambiguity as the bureaucracy which was intended to enforce it, with the same underlying reversion to an earlier prototype. For mercantilism undoubtedly demanded the suppression of particularistic barriers to trade within the national realm, and strove to create a unified domestic market for commodity production. (Anderson, 2013, p. 35)

The national reality, product of the modernity as attested by Hobsbawm, emanates from the interrelation of these three elements: market, State and capitalism. Political economy is a way of understanding the economics of the modern States and has a practical dimension, an economic policy, and a theoretical one, the political economy properly said. The idea of nation is considered, inside political economy, as a market with political frontiers and an identity.

The formation of the German nation is marked by several paradoxes. First, the political territory does not precede the economic territory: the State is a result of successive measures of customs union between different kinds of territories - principalities, duchies, grand-duchies, kingdoms and free cities-since the Napoleonic invasions. The first economic union proposal, a project of the German Confederation, made around 1818, is replaced in 1834 by the Zollverein. Besides tariffs, the railroads construction, connecting different regions, is other relevant economic factor in unification. The issue of German industrialization also influences the way that German nation is thought. Late in relation to Great Britain, the German industry needed a State that had as its main goal the industrialization and the national economic development. The List's idea of nation, as a set of productive forces in cooperation, is molded by the unification projects and the industrialization effort. 
In second place, the nineteenth century is, in Prussian Empire, a century of history's studies appreciation. History is a way of thinking, from political economy to romanticism, it is the essence of any scientific knowledge, including of political economy. The German political economy authors, such as List and Schmoller, do not use History simply for illustration purposes, history appears on them as an evolutionary process that has national specifities. Although some studies say that is controversial the existence of a German Historical School, the recource to history was a commonplace to the nineteenth century German thinkers.

Here there is a space to an observation about the late character of German unification, since this is why German intellectuals develop a historical conception of nation that, as we said, goes from literature to philosophy, and from this to political economy: "In the period from the mid-seventeenth century to the abolition of the Holy Roman Empire under Napoleonic rule in 1806, a unique pattern of political multiplicity existed in German lands" (FULBROOK, 2004, p. 69). The fragmentation since the Lutheran Reformation period, in which the principalities used the reform as an instrument of struggle against the emperor and the Pope, was reinforced by the Thirty Years'War and the seventeenth century crisis. The seventeenth century crisis gave new energy to local authorities, inhibiting the territorial unification and the Absolutist state formation. ${ }^{1}$ Besides the Thirty Years' War, in which the Habsburgs were involved directly, the trade routes that passed through the German lands were suppressed because of the shift from the Mediterranean to the Atlantic. The result was the alliance between the landowner nobility or territorial cities and local leaders, strengthening the political power of the first ones. The Holy Roman Empire did not serve, in Prussian lands, as an "active political vehicle or potential basis for the development of a centralised State" (FULBROOK, 2004, p. 85), since the Habsburg struggles against the Papacy reinforced the local powers in medieval hierarchy: "its continuing juridical functions (of the Holy Roman Empire) and rather passive political protection permitted the survival of many small units, fragments which without this wider context might easily have been submerged by larger neighbours" (Idem, p. 85). Only with the end of the Holy Roman Empire, in 1806, people began to think of a State project, founded in the "Little Germany" unification and led by Prussia against Austria. It is in this context and within this project that aims to supplant the Kleinstaaterei that List outlines his view of the nation. Let us not forget, however, that the idea of a big and strong territory, in the frames of the capitalism expansion is something common to other States, and, among these, the United States, which will be List's residence during his exile.

The third paradox refers to the kind of liberalism that has complied and that also influences our author. List is a liberal political, but he is not an economic liberal. He is in favor of the democratic government, more precisely, the establishment of a parliament or a German diet, but not of the protectionism abolition. For him, the freedom Smith preaches is nothing but a misunderstanding:

(...) we meet with a misconception which has been the parent of much error, occasioned by the misuse of the term "freedom". Freedom of trade is spoken of in the same terms as religious freedom and municipal freedom. Hence the friends and advocates of freedom feel themselves especially bound to defend freedom in all its forms. And thus the term "free trade" has become popular without drawing the necessary distinction between freedom of internal trade within the State and freedom of trade between separate nations, notwithstanding that these two in their nature and operation are as distinct as the heaven is from the earth. For while restrictions on the internal trade of a state are compatible in only very

\footnotetext{
1 The religious reform is one aspect of the crisis, which, according to Trevor-Roper, was characterized by the society struggle against the State. One of the clearest results was the absolutism outlined by the mercantilism, which is considered the economic and political solution to the seventeenth century crisis (TREVOR-ROPER, In SANTIAGO, 1974).
} 
few cases with the liberty of individual citizens, in the case of international trade the highest degree of individual liberty may consist with a high degree of protective policy. (LIST, 1909 (1841), p. 9)

And also:

That, however, under the existing conditions of the world, the result of general free trade would not be a universal republic, but, on the contrary, a universal subjection of the less advanced nations to the supremacy of the predominant manufacturing, commercial, and naval power, is a conclusion for which the reasons are very strong and, according to our views, irrefragable. A universal republic (in the sense of Henry IV. and of the Abbé St. Pierre), i.e. a union of the nations of the earth whereby they recognise the same conditions of right among themselves and renounce self-redress, can only be realised if a large number of nationalities attain to as nearly the same degree as possible of industry and civilisation, political cultivation, and power. (LIST, 1909 (1841), p. 103)

It's necessary to draw attention to the liberalism-protectionism paradox because it is the focal point of the nation-States formation process on the continent, a State following the disintegration of the absolutist State and transforming the economic development in a political project. From the mid-nineteenth century, a series of protectionist measures are adopted by the countries against the English liberal measures. Prussia, because of inherent difficulties in the process of unification, anticipates this process, using protectionism as an instrument of unification itself. Defining a new idea of freedom, which guides the Prussian intellectuals, we find a new conception of nation. Be in Herder or List, the nation assumes the existence of a cultural community, a Volk, where cultures are seen as an organic whole that has a certain history:

By rejecting the Enlightenment revulsion against the Middle Age, there was a revival of history interest and, in particular, in popular history. This would lead to romanticism and interest in folklore during the nineteenth century, as with the Grimm brothers. This process would eventually develop the notion that cultural nation (Volk) and political unity (State) were contiguous. (FULBROOK, 2004, p. 110)

The war against the napoleonic domain served to transform the Prussian culture in a political nationalism. This established and brought organicity to culture, from which the intellectual productive forces, responsible for the material development of the nation, were born.

In the process of the German Confederation constitution, in 1815, the paradox between liberalism and protectionism becomes more evident. Despite the proposed abolition of economic barriers between the confederacy territories, no political project of a unified and a centralized State was proposed. The Confederation was not a Bundesstaat, but Staatenbund, what means that the territory maintained its authority. Although the acquisition of Rhineland and Westphalia by Prussia represented considerable economic gains, it lacked a policy worried about the development of the trade and the industry in the annexed regions. Small powers in the regional level prevailed, rather than the unified project led by Prussia. The paths to the German political unification were difficult, hence the importance of a unified market construction. For that, a protectionist policy would be a central point and the unified State would have the title-role in the agriculture and industry development; in education investment; in railways construction. On the other hand, a strong State is an industrial State:

The system of protection, inasmuch as it forms the only means of placing those nations which are far behind in civilisation on equal terms with the one predominating nation (which, however, never received at the hands of Nature a perpetual right to a monopoly of manufacture, but which merely gained an advance over others in point of time), the system of protection regarded from this point of view appears to be the most efficient means of furthering the final union of nations, and hence also of promoting true freedom of trade. (LIST, 1909 (1841), p. 103) 
To elucidate the paradox of German liberalism, it is necessary to keep in mind, firstly, the malleability of liberal ideology, as stated by Pierre Rosanvallon, and, secondly, List's concept of freedom that is not a synonym of economical liberalism.

Liberalism, as the ideology of capitalism, can be used in different senses, but to achieve the same objective: completing the process of capitalist development. Then, it can be in favor of free trade or protectionist since it's the primal objective of increasing industrial forces that must be pursued:

It is from this conception that the origin of all criticisms to capitalism should be investigated; paradoxically these criticisms consist in accusing it of not being faithful to itself (being statist or protectionist); or of being excessively faithful (...). This ambiguity is only the result of the misunderstanding betueen the capitalism as a result of social practices and capitalism as a theoretical system. (...) Let us take the protectionism example. One can only explain it and understand its permanence throughout the nineteenth century with the double condition of understanding the capitalism as a result of social practices and as an evidence of the utopian character of the liberal ideology. (ROSANVALLON, 2002, pp. 246-247)

In this sense, the Prussian Empire had regions that differed in the liberalism conceptions. Northern liberals were more conservative and defensive, while southern liberals were more radical.

Secondly, when we specifically look at the German case and the German Enlightenment's concept of freedom, the constitution of the individual freedom and the building of a strong state are not exclusionary processes. The liberals in the nineteenth-century in Prussia were, in general, members of the professional middle class, sometimes bureaucrats and passionate supporters of the State institution:

The German variant of the Enlightenment, the Aufklärung, arose somewhat later than the English and French Enlightments and had its own distinct emphasis. (...) In its different political and social context, the German Aufklärung remained more compatible with established religion and established authoritarian forms of rulership. (...) Curiously, another generalisation that has come down about the German Enlightenment in particular is that it was essentially apolitical in implication, separating freedom in the sphere of thought and the spirit from obedience to worldly authority. (...) The enlightened civil servants and pastors did not question the authority of their princes because in many cases they did not have to; they sought to effect improvements in administration through good government under enlightened rulers. (...) but in the main, the German Enlightenment in the context of Kleinstaaterei could be carried by state-dependent, state-sustaining, professional classes, rather than independent critical intellectuals as in France. (FULBROOK, 2004, pp. 89-91)

In this sense, a particular Enlightenment with a particular conception of freedom forged a different idea of nation that, instead of the precepts of The Wealth of Nations, proposed the existence of a strong State that would pursue the development of national productive forces. Freedom organized by a national State is superior to the freedom of individuals following nothing but only their selfish interests: "However industrious, thrifty, inventive, and intelligent, individual citizens might be, they could not make up for the lack of free institutions" (LIST, 1909 (1841), p. 87).

The reflection of List is one of the expressions of a new nation concept, no longer based on the sum of a set of individuals living within the same territory, but on the synthesis of their interests organized by the State. These interests, along with the culture and politics, represent a strong sense of identity:

WE have proved historically that the unity of the nation forms the fundamental condition of lasting national prosperity; and we have shown that only where the interest of individuals has been subordinated to those of the nation, and where successive generations have striven for one and the same object, the nations have been brought to harmonious 
development of their productive powers, and how little private industry can prosper without the united efforts both of the individuals who are living at the time, and of successive generations directed to one common object. (LIST, 1909 (1846), p. 132)

This new conception of nation, understood as an aggregate of productive forces, is formulated in opposition to the concept of nation in English political economy, understood as a market set in international division of labour. It's, in some sense, a product of the Spring of Nations and the fights against the Ancient Regime.

\section{The Political Economy as a National System}

The National System of Political Economy, published in 1841, five years before the author's death, consists in four books: History; Theory; Systems; Policies.

The order of exposure of the book is important because it shows, immediately, a reversed relation to the construction of The Wealth of Nations by Adam Smith. In List, History is the first book and occupies a prime place in argument formulation. History is not simply a set of examples that serve to illustrate the theory. It is the starting point and expresses an evolutionary concept of society. History serves to understand the specific features of different nationalities and to formulate economic policies applied to nations development. Moreover, the economic policy study, which provides the third and forth parts of the book, is the more important part of the theory formulation because this theory must be conducted by practical principles or it can be useless. On the other hand, Systems and Policies, the third and fourth parts, respectively, are in the center of the perception of the nationalities existence.

Political economy, the object of the second part, assumes a different position from the political economy in Adam Smith's theory. Political economy in List does not involve a search of the natural laws of market functioning, but the distinction between the economy of individuals and economy of a society, between the real political or national economy and the cosmopolitical economy. It is in nationality, after all that the true nature of things lays:

If we wish to remain true to the laws of logic and of the nature of things, we must set the economy of individuals against the economy of societies, and discriminate in respect to the latter between true political or national economy (which, emanating from the idea and nature of the nation, teaches how a given nation in the present state of the world and its own special national relations can maintain and improve its economical conditions) and cosmopolitical economy, which originates in the assumption that all nations of the earth form but one society living in a perpetual state of peace. (LIST, 1909 (1846), p. 99)

The second part, Theory, presents the themes of the classical political economy circumscribed by very objective aspects: the formation of national productive forces; the nature of the nationalities; the manufacturing potential of nations; the division of national and international work; the role of colonies and the power of the States. These aspects define the economic nature of power of a nation State. In some way, it is pragmatism of the ideas that can define List's work, the importance of the political economy as an objective science, not as an abstract one. This was, until then, the tradition: from French political economy to English political economy.

The first book begins with a concrete movement toward history; the third and fourth books are suggestions around economic policy and political practices, therefore; and the second book, although titled Theory, it is a political economy of concretely defined nations by their territories and their productive forces. 
We will focus our efforts on the analysis of the second book, because it's in this book that there is the greatest number of references to List's nation definition. However, we will make references to other parts of the book, as far as they are necessary to think the idea of nation that emerges in the nineteenth century and which List is one of the main exponent.

The first observation about nation in List is that it derives from a conception of society that is not just a sum of isolated individuals that go to market to accomplish their exchanges. To Smith, nation is a kind of market with political frontiers and market is the most fair form that society can undertake. Although the nation existence can be related to market; to List, nation has a collective basis which cannot be summarized in independent subjects put in the same territory. It is something different and it is only in this sense that nation can be thought of as "imagined community" (ANDERSON, 2005). This social construction is necessarily a historical process, and it is on this one that we should think about to achieve the full development potential. The State is a fundamental agent in wealth nation production:

Everywhere and at all times has the well-being of the nation been in equal proportion to the intelligence, morality, and industry of its citizens; according to these, wealth has accrued or been diminished; but industry and thrift, invention and enterprise, on the part of individuals, have never as yet accomplished aught of importance where they were not sustained by municipal liberty, by suitable public institutions and laws, by the State administration and foreign policy, but above all by the unity and power, of the nationpublic laws, in public administration and a foreign policy and, especially, in unity and strength of the nation. (...) History everywhere shows us a powerful process of reciprocal action between the social and the individual powers and conditions. (LIST, 1909 (1841), p. 87)

Using political economy to think about nation as a collective unit contradicts the most fundamental assumption of classical political economy: that society is a group of individuals who, following their own interests, increase social well-being involuntarily. The nation or society would be a sum of individuals. To List, by assuming that, political economy acquires a universal character, losing its power of explaining particular situations. On the opposite, to List nation is a political unit sui generis, which differs from a set of individuals as well as from a city-State. The author begins the historical book precisely by the Italians, with the purpose of pointing out that systems of political economy, which corresponds to the set of rules concerning the practice of economic policy, may become obsolete over time:

From the example of Venice (so far as it may be adduced against a protective commercial policy at the present time) neither more nor less can be inferred than this - that a single city or a small state cannot establish or maintain such a policy successfully in competition with great states and kingdoms; also that any power which by means of a protective policy has attained a position of manufacturing and commercial supremacy, can (after she has attained it) revert with advantage to the policy of free trade. (LIST, 1909 (1841), p. 9)

It is interesting understand the subtleness of the historical argument: each political unit, historically defined, must have its own political economy system. The mercantile system, as Adam Smith called what we might call mercantilism, is still a remnant of the city-States. To List, however, the mercantile system, is much closer to the necessary system of development of a nation than the system proposed by Smith, the free trade. Unless within a world in which each nation had already reached the same stage of development, which is a historical impossibility, free trade would never contribute to the development of a nation, thought as a State and not as a market. As the city-State has its own political economy system, a nation State must have its own political economy system fundamentally based in protectionism. 
Adam Smith's doctrine is, in respect to national and international conditions, merely a continuation of the physiocratic system. Like the latter, it ignores the very nature of nationalities, seeks almost entirely to exclude politics and the power of the State, presupposes the existence of a state of perpetual peace and of universal union, underrates the value of a national manufacturing power, and the means of obtaining it, and demands absolute freedom of trade. It is just an extension of the Physiocratic system. As the latter, it ignores the nature of nations, it seeks to exclude, almost totally, the political and State power, presupposes the existence of a State of perpetual peace and universal union, underestimate the value of a national manufacturing force, and the means to achieve this objective, and requires absolute freedom of trade. (LIST, 1909 (1841), p. 277)

Continuing, List defines a system of national economy as opposed to the private economy system:

It is a further sophism, arrived at by confounding the theory of mere values with that of the powers of production, when the popular school infers from the doctrine, "that the wealth of the nation is merely the aggregate of the wealth of all individuals in it, and that the private interest of every individual is better able than all State regulations to incite to production and accumulation of wealth," the conclusion that the national industry would prosper best if only every individual were left undisturbed (...) This system everywhere takes into its consideration only individuals who are in free unrestrained intercourse among themselves, and who are contented if we leave everyone to pursue his own private interests according to his own private naturalxinclination. This is evidently not a system of national economy, but a system of thexprivate economy of the human race, as that would constitute itself were there no interference on the part of any Government, were there no wars, no hostile foreign tariff restrictions. (LIST, 1909 (1846), p. 137-138)

The German unification became a matter of survival of various Germanic territories in a world composed of organized States that made capitalist development in their territories the prerequisite for their sovereignty over the other States. The non-unification placed German states in an underprivileged position in relation to their competitors in the international market and prevented the continuity of the transformations that had been happening since 1830. As Arrighi says, it was from the German unification processes, and, in the case of the United States, from its frontiers expansion that a new form of imperialism would emerge:

Even though control over world commerce and finance continued to play an important role in determining relative capabilities in the inter-state system, in the course of nineteenth century the decisive advantage in the struggle for world power had become the comparative size and the growth potential of the domestic market. (ARRIGHI, 1994, p. 61)

The Prussian Confederation had seen an improvement in the communication system since the beginning of nineteenth century, including a modern rail system and the introduction of steamships in Reno. Factories were established in Borsig and Berlin for locomotives production. The textiles production was greatly modernized from the dyeing industry, which would be the trigger of the German chemical industry. The most substantive change, however, refers to the transition from servile labor to free one in many regions of the country. The figure of the working class became increasingly common in Prussian society, while, although still quite common, the independent producer was losing space. A society based on feudal status started giving place to class society, which became increasingly evident from 1830, the point of transformation advocated by List.

To List, a territory not yet unified disturbed the development of productive forces, thus the support for a Customs Union project, the DeutscherZollverein, defended actively by List. In Germany, the movements in towards economic unification announced the shape that the political unification should take that is the economic territory or the market preceding the political territory. The political territory or State happened along with the capitalism consolidation. Since the idea of nation and its strong economic content, which is also a justification for the State consolidation, is the prerequisite for the capitalism development. Economics and politics are 
interconnected and are from this relationship that imperialisms of the late nineteenth century will originate:

Plainly, the world economy was not longer, and it had been in the mid-nineteenth century, a solar system revolving around a single star, Great Britain (...) her relative decline was patent. A number of competing national industrial economies now confronted each other. Under these circumstances economic competition became inextricably woven into the political, even the military actions of the states. The renaissance of protetionism during the Great Depression was the first consequence of this merger. From the point of view of capital, political support might henceforth be essential to keep out foreign competition, and perhaps essential too in parts of the world where the enterprises of national industrial economies competed one another. From the point of view of states, the economy was henceforth both the very base of international power and its criterion. It was impossible now to conceive of a "great power" which was not at the same time a "great economy". (HOBSBAWM, 1989, p. 317)

It is necessary, however, to distinguish between economics and politics in the mercantilism and in the capitalism. In that, the economy is an extension of politics, has no self existence. In capitalism, the economy is the essence of the mode of production, but neither exists without politics, hence we refer to political economy as a scientific representation of capitalism. Only a cohesive national State could have colonies that would allow it to reach the industrial development, which was not directly aimed in mercantilism. In this, the State enrichment fed its absolute power; in capitalism, wealth increases the power of a State in the sense of expanding its sovereignty and its decision making ability in the international arena. The financial, industrial and technological powers are instruments for the extension of political power. According to Arrighi, the relationship between capital accumulation and power accumulation constitutes a dialectical relationship in capitalism:

The close historical tie between capitalism and the modern inter-state system is just as much one of contradiction as it's of unity. We must take into account the fact that 'capitalism and national states grew up together and presumably depended on each other in some way, yet capitalists and centers of capital accumulation often offered concerted resistance to the extension of state power'. In our account, the division of the world-economy into competing political jurisdictions does not necessarily benefit the capitalist accumulation of capital”. (ARRIGHI, 1992, p. 32)

According to Hobsbawm, the possession of colonies relates directly to nation definition as a great and powerful territory (HOBSBAWM, 1992).

Given this close relationship between power and economy, protectionism, for List, was not only a necessary expedient. It was mandatory for all nations wishing to develop and to become powerful: "The idea of independence and power originates in the very idea of 'the nation"' (LIST, 1909 (1846), p. 146). The free-trade laws were only valid for States with similar levels of development. Protectionism implied a temporary sacrifice of material productive forces, which were compensated by the centuplication of the intellectual and material forces (exchange value) on a next moment. If the Prussia kingdom had a potential manufacturing as large as the British Empire, there would be no problem in free trade. Before that, it was necessary that the unifying Germany developed completely its manufacture. The development of manufacturing was directly linked to the degree of civilization and intelligence of a nation, as well as its individuals. An industrial was much more skillful and intelligent than a farmer, so it was so necessary that Germany ceased to be an agrarian society to become an industrial society.

List's concept of productive forces states the idea of immaterial or intellectual work. To List, Smith had an excessive materialistic view of labor, which annulled his principles for nations in development process, such as Germany. For these nations, the intellectual forces preceded and developed the physical labor, in the same way 
that mental work and manufacture developed agricultural work:

His investigations are limited to that human activity which creates material values. With regard to this, he certainly recognises that its productiveness depends on the "skill and judgment" with which it is exercised; but in his investigations as to the causes of this skill and judgment, he does not go farther than the division of labour, and that he illustrates solely by exchange, augmentation of material capital, and extension of markets. His doctrine at once sinks deeper and deeper into materialism, particularism, and individualism. If he had followed up the idea "productive power", without allowing his mind to be dominated by the idea of "value", "exchangeable value", he would have been led to perceive that an independent theory of the productive power, must be considered by the side of a theory of values in order to explain the economical phenomena. (LIST, 1909 (1841), p. 111)

Therefore, the labor value theory is replaced, in List, by the theory of productive forces, which expresses the efforts of the late nations to accelerate their industrialization, reducing the gap with England and winning a place in the international arena. The prosperity of a nation does not increase in proportion to accumulated wealth, but to the extent that it accumulates productive forces: "The whole social state of a nation will be chiefly determined by the principle of the variety and division of occupations and the cooperation of its productive powers" (LIST, 1909 (1841), p. 129) continuing:

The causes of wealth are something totally different from wealth itself. (...)The power of producing wealth is therefore infinitely more important than wealth itself; it insures not only the possession and the increase of what has been gained, but also the replacement of what has been lost (...)The popular school of economists would have us believe that politics and political power cannot be taken into consideration in political economy. (LIST, 1909 (1841), pp. 108-114)

To List, politics makes economics a real and different science of cosmopolitical economy or the "popular school" of economics. In this sense, perhaps, from the mid-nineteenth century, it is increasingly difficult the separation between economics and politics, as exposed in the above excerpt taken from Eric Hobsbawm.

The principle of labor division, which, in Smith, is based on the relationship between individuals who follow their own interests, in List, is essentially national. When, these principles are national, they do not mean division, but cooperation. And, the forces that rule the division of domestic labor cannot rule the international division of labor because in this case, there are other interests: interests related to the power of a State, which is different from individual interests.

Similarly as a single manufacture thrives by the combination of productive forces of individuals, a set of manufactures flourishes in the combination of their productive forces with other manufactures. Then a division of domestic labor, observed between industry and agriculture, as well as among industries, is evolved:

The popular school, inasmuch as it does not duly consider the nature of the powers of production, and does not take into account the conditions of nations in their aggregate, disregards especially the importance of developing in an equal ratio agriculture, manufactures and commerce, political power and internal wealth, and disregards especially the value of a manufacturing power belonging specially to the nation and fully developed in all its branches. (...)In like manner the entire manufacturing industry of a State in connection with its agricultural interest, and the latter in connection with the former, will prosper the more the nearer they are placed to one another, and the less they are interrupted in their mutual exchanges with one another. The advantages of their confederation under one and the same political Power in times of war, of national differences, of commercial crises, failure of crops, are not less perceptible than are the advantages of the union of the persons belonging to a pin manufactory under one and the same roof. (...) The most important division of occupations, and the most important co-operation of productive powers in material production, is that of agriculture and manufacture. (LIST, 1909 (1846), p. 114-129) 
It is from the cooperation between the productive forces of different qualities that derives the power of a State. The idea of nation from the mid-nineteenth century comes from the identity between economy and politics during the period of consolidation of capitalism. It's clear that, to the extent of the rise of new contradictions in the capitalist mode of production, different conceptions of nation are invented and these conceptions can only be understood as a product of capitalism history, not as an abstract cultural construction. The State from the mid-nineteenth century is defined by nation, but a nation that, paradoxically, is not the small nation of the principle of nationality, but the nation that combines the productive forces of a given territory and shapes a particular identity. Also for this reason, Hobsbawm would say that if nationalism is the internal aspect of movements that characterize the Spring of People, imperialism would be its external projection. The novelty represented by the idea of nation suffers a reversal in the mid nineteenth. From the principle of nation, that proclaimed to each people one land, the idea of nation became synonym of a prosperous and rich territory (HOBSBAWM, 1990). It is this change that is the nation reflected in List's text, that we will study in the next item.

\section{Nation as Novelty on List}

To draw a precise relationship between political economy in List and his idea of nation, it was necessary, one first movement that consisted in situate the role of history in the German thought. The idea of nation in List was an expression of a revolutionary idea, which was built with the Spring of Peoples movement, in 1848, and which referred to a new form of State, the nation-State. Other thinkers, in other countries of late industrialization, as Alexander Hamilton, in the United States, were also concerned with the creation of a new political economy that served to achieve concrete objectives of economic policy.

Secondly, we have presented List "theory" as an unfolding of the economic policy objectives, and not otherwise. To List, the classical political economy, from British empiricist tradition, cannot be applied to the purpose of German development because besides of being too abstract, it serves to English interests of maintaining its monopolistic industrial position in the world. Thinking of a new political economy that takes into consideration that there are different grades of development among countries, List suggests knowing the national past of a country in order to make plans for its development. One artifice needed, as presented, is protectionism.

Third, List's conception of society is a synthesis and not a sum of individuals: "the wealth of nations is to be attained in a manner different to that of the private rentier" (LIST, 1909 (1841), p, 188). This conception of society reflects in the way he imagines nation. This idea of nation, as a community that comprehends territorial ties, is a product of the period 1840 to 1870 . Prussia, that leads the unification project of small German, is a central element in this process.

In this last item of our paper, we put Friedrich List's study into a broader context, wondering about the contradictions involved in the national ideas construction. Why does the nation move from a cultural conception, based on the nationality principle, according to which each people should have its own territory, to a political economic conception? Is the nation a product of capitalism? Why are Germany and the United States the clearest expression of a new conception of nation, emerging in the mid-nineteenth century? And, why is it emerging at this moment? It's by List's study that we intend to clarify these contradictions. 
List's work is in a context to which converge the processes of the formation of capitalisms in Europe; the abolitions of servitude where it still existed; the beginnings of the destruction of the Ancient Regime, as the Austrian Empire, German, Russian and Ottoman empires; the processes of capitalist industrialization in the continent and in the United States; processes of late unification, among which include Germany, Italy and Poland, and may also include the United States and Russia, if we think about the unification process as a process of creating new frontiers.

In German Confederation, it is due to the late unification that a new idea of nation, based on an economic conception of territory, was made up. In the United States of Alexander Hamilton, it is no different, as shown by the excerpt extracted from Report on Manufactures, written in 1791:

This is a much more powerful mean of augmenting the fund of national Industry than may at first sight appear. It is a just observation, that minds of the strongest and most active powers for their proper objects fall below mediocrity and labour without effect, if confined to uncongenial pursuits. And it is thence to be inferred, that the results of human exertion may be immensely increased by diversifying its objects. When all the different kinds of industry obtain in a community, each individual can find his proper element, and can call into activity the whole vigour of his nature. And the community is benefitted by the services of its respective members, in the manner, in which each can serve it with most effect. (...) This also is of greater consequence in the general scale of national exertion, than might perhaps on a superficial view be supposed, and has effects not altogether dissimilar from those of the circumstance last noticed. To cherish and stimulate the activity of the human mind, by multiplying the objects of enterprise, is not among the least considerable of the expedients, by which the wealth of a nation may be promoted. Even things in themselves not positively advantageous, sometimes become so, by their tendency to provoke exertion. Every new scene, which is opened to the busy nature of man to rouse and exert itself, is the addition of a new energy to the general stock of effort. (...)

The spirit of enterprise, useful and prolific as it is, must necessarily be contracted or expanded in proportion to the simplicity or variety of the occupations and productions, which are to be found in a Society. It must be less in a nation of mere cultivators, than in a nation of cultivators and merchants; less in a nation of cultivators and merchants, than in a nation of cultivators, artificers and merchants. (HAMILTON (1791), 1904, pp. 210-211)

Both in List and in Hamilton, the separation between economics and politics is very slight since wealth is synonymous of power and the State is defined by the set of its productive forces and by the degree of development of its industry. This notion of territory, both political and economical, will be the basis for defining the nation in the nineteenth century. The last List's books, Systems and Politics, are devoted to deny English political economy and rescue the mercantilist heritage that would have pointed to the real systems of political economy, as they were based on nationality and not on free trade. As capitalism had reached a certain stage of development, it was no longer possible to go on without the support of the State, particularly in the case of late industrialization countries, as the United States and Germany. Germany of List did not exist when he wrote his book; in the first half of the nineteenth century, most of the population of close territories to Prussia lived in the country, and the food supply was very precarious. Tumults happened because of food shortages. Rural unemployment and migration movements increased in 1848. The idea of nation, as a brotherhood or a community, became to be grounded not only in cultural principles, but also in economic principles, based on ties that bounded the members of a corporation and extended themselves to all territory that was under the jurisdiction of a State. According to List words:

(...) Between each individual and entire humanity, however, stands THE NATION, with its special language and literature, with its peculiar origin and history, with its special manners and customs, laws and institutions, with the claims 
of all these for existence, independence, perfection, and continuance for the future, and with its separate territory; a society which, united by a thousand ties of mind and of interests, combines itself into one independent whole, which recognises the law of right for and within itself, and in its united character is still opposed to other societies of a similar kind in their national liberty, and consequently can only under the existing conditions of the world maintain self-existence and independence by its own power and resources... (LIST, 1909 (1846), p. 141)

The nation as defined by List expresses very well the concept of nation that took place in the mid to late nineteenth century, between the era of revolutions and the age of empires. For Hobsbawm, nationalism had become one of the central protagonists of the political scenery since 1848 (HOBSBAWM, 1990). The national education policies, homogenization of language, unity of customs tariffs took part of the national States' agenda and were part of two interrelated processes: the consolidation of the national States and of capitalism.

Unlike the liberal arguments, the capitalist economy was never made without politics or in spite of it, the above excerpt by Giovanni Arrighi indicated. The economy, by contrast, is an extension of the political sphere; the markets are connected to States; where territorial unification and the formation of a State had not yet occurred, they began to be claimed by the forces of capitalist establishment:

For List, the task of economics, which Germans henceforth tended to call "national economy" (Nationaloekonomie) or "people's economy" (Volkswirthschaft) rather than "political economy" was to "accomplish the economic development of nation and to prepare its entry into the universal society of the future". One need hardly add that this development would take the form of capitalist industrialization pressed forward by a vigorous bourgeoisie". (HOBSBAWM, 1990, pp. 29-30)

The way by the German unification was made, beginning with the definition of the economic territory to the after formation of the political territory, going from market to State, explains some of the paradoxes of nineteenth century nation idea. Despite the prerogatives of the principle of nationality, according to which each people had right to a territory, it was the large territory (with a multitude of people, languages and cultures) that prevailed upon the small one:

(...) what is interesting from our point of view about List, and the later "historial school" of German economists who took him as their inspiration - as did economic nationalists of other countries like Arthur Griffith of Ireland-is that he clearly formulated a characteristic of the "liberal" concept of the nation which was usually taken for granted. It had to be sufficient size to form a viable unit of development. If it fell bellow this threshold, it had no historic justification. (HOBSBAWM, 1990, p. 30)

This inversion of order between the establishment of the national market and the national State in Germany is able to explain many of the misunderstandings around the idea of nation and the ideology of nationalism. In German case, the idea of nation essentially economic. National identity cannot be clearly characterized by culture or a language (that is so diverse among multiple German territories), being defined mainly by a set of productive forces that should be constructed. Where national States precede the consolidation of capitalism, as it is in most European States, nationalism invents the nation and legitimizes the State. Where there is no national State, as in the German case, the idea of nation precedes the State, which appears as a result, not a cause of unification. Since the formation of the Prussian Confederation, in 1815, which was born from negotiations of the Congress of Vienna, until the rise of the Second Reich, in 1870, it is the market, headed by the Kingdom of Prussia that commands the unification of territory. A political project of the German nation derived from the unification of customs tariffs: 
The increased effectiveness of the Confederation, in fact, was one of the major stimuli to a national opposition after 1815 of far greater importance that the intellectual concerns with romantic and ethnic nationalism. Political opposition in the smaller German states was rather than more advanced than in Prussia and Austria, partly owing to the impact of French reforms and influence. (BREUILLY, 1998, p. 100)

Rebuild the nation, according to List, implies respecting the multiple possibilities of relationships between State, nation and nationalism. The author's idea of nation that comes before the German nationalist movement and before the formation of the German State, lights a lot of paradoxes that involves nation as a cultural community or as an invention. Despite these definitions are correct, they cannot be separated from the general process of establishment of capitalism. The political economies and the distinct contexts that they were formulated are a good guide in the discovery of the economical ties in national communities.

\section{References}

Adler, P. (2011). Political economy. In Tadajewki, M. et al., Key concepts in critical management studies. London: Sage Publications.

Anderson, B. (2006). Imagined communities: Reflections on the origin and spread of nationalism. London; New York, NY: Verso. Anderson, P. (2013). Lineages of the absolutist state. London; New York: Verso.

Arrighi, G. (1994). The long twentieth century: Money, power, and the origins of our times. London: Verso.

Boianovsky, M. (2013). Friedrich List and the Economic Fate of Tropical Countries History of Political Economy. History of Economic Thought (HOPE), 45(4), 647-691.

Breuilly, J. (1985). Nationalism and the state. Manchester: Manchester University Press.

Levi-Faur, D. (1997). Friedrich List and the political economy of the nation-state. Review of International Political Economy, 4(1). Fontana, J. (1982). Historia: Análisis del pasado y proyecto social. Barcelona: Editorial Crítica.

Fulbrook, M. (2004). A concise history of Germany. Cambridge (England); New York: Cambridge University Press.

Gellner, E. (2008). Nations and Nationalism. Ithaca, N.Y: Cornell University Press.

Hamilton, A. (1904). "Report on manufactures". In The Works of Alexander Hamilton. (pp. 192-284). Org. Lodge, Henry Cabot.

New York, London: G.P. Putnam's Sons.

Hobsbawm, E. J. (1989). The age of empire (1875-1914). New York: Vintage Books.

Hobsbawm, E. J. (1990). Nations and nationalism since 1780: Programme, myth, reality. 2nd ed. New York: Cambridge University Press.

Hobsbawm, E. J. (1999). Industry and empire: From 1750 to the Present Day. Penguin UK.

List, G. F. (1909). The national system of political economy. (1841). Translated by Sampson S. Lloyd. New Yoirk, Bombay and Calcuta: Longmans Green and Co.

Pohlsander Hans, A. (2008). National Monuments and Nationalism in 19th Century Germany. Series: New German-American Studies/Neue Deutsch-Amerikanische Studien. Vol. 31. Oxford, New York.

Rosanvallon, P. (1989). Le Libéralisme économique: Histoire de l'idée de marché. Paris: Le Seuil. 